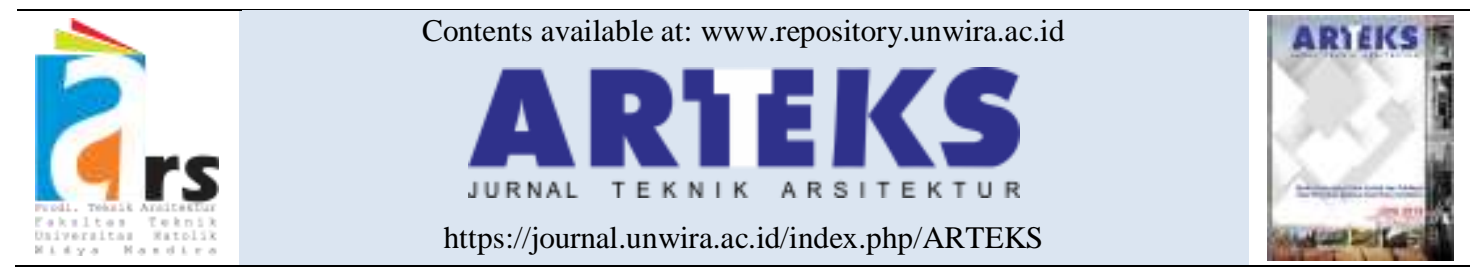

Research paper

doi: $10.30822 /$ arteks.v6i3.760

\title{
A study on interlocking brick innovation using recycled plastic waste to support the acoustic and thermal performance of a building
}

\section{Heyder Ahmed*', Sugini}

Master of Architecture, Faculty of Civil Engineering and Planning,

Universitas Islam Indonesia

Jl. Kaliurang km. 14,5 Sleman, Yogyakarta, Indonesia

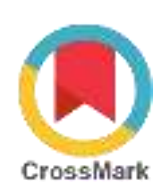

\begin{tabular}{|c|c|}
\hline ARTICLE INFO & ABSTRACT \\
\hline $\begin{array}{l}\text { Article history: } \\
\text { Received Nov. } 30,2020 \\
\text { Received in revised form Feb. 24, } 2021 \\
\text { Accepted June } 28,2021 \\
\text { Available online December } 01,2021\end{array}$ & $\begin{array}{l}\text { The main materials used in producing interlock bricks are clay, } \\
\text { sand, and cement as usually applied in the conventional process of } \\
\text { making bricks. There is, however, a continuous reduction in the } \\
\text { availability of these natural resources due to their non-renewability. } \\
\text { Therefore, one of the materials with the ability to support the }\end{array}$ \\
\hline $\begin{array}{l}\text { *Corresponding author: Heyder Ahmed } \\
\text { Master of Architecture, Faculty of Civil } \\
\text { Engineering, Univesitas Islam Indonesia } \\
\text { Email: } 18922004 @ \text { students.uii.ac.id } \\
\text { ORCID: https://orcid.org/0000-0001-6790- } \\
6227\end{array}$ & $\begin{array}{l}\text { acoustic and thermal performance of buildings in architecture is } \\
\text { plastic. Plastics are categorized as lightweight, non-breakable, non- } \\
\text { corrosive, and resistant to weather. Moreover, there is no need for } \\
\text { the production of new plastics for this purpose due to the global call } \\
\text { for the use of plastic wastes based on their high economic value. } \\
\text { Therefore, this research aimed to compile a study on interlock brick } \\
\text { innovation using recycled plastic waste to support the acoustic and } \\
\text { thermal performance of a building. This was conducted through a } \\
\text { review of previous studies on the profile of interlock bricks produced } \\
\text { from recycled plastic waste. The findings are expected to provide } \\
\text { information on the efficient production of interlock brick innovation } \\
\text { using plastic wastes as a component. }\end{array}$ \\
\hline
\end{tabular}

\section{Introduction}

New methods are being introduced to the process of making bricks in the last two decades in order to reduce the weaknesses of the old method and an example of this is the introduction of the interlocking brick (Al-Fakih et al. 2018). This is considered an alternative component for sustainable development in several countries (Watile, Deshmukh, and Muley 2014; Pradono 2019; Prastyatama and Maurina 2018)with its application observed in housing and water infrastructure construction (Susilawati and Tyas 2018). There is, however, a need for sustainable technology in its production such as the use of locally available natural resources to reduce transportation and ensure easy, environmentally friendly, time-efficient, and energy-efficient process (Deepak 2012). This is expected to produce interlock bricks that are not only superior in terms of method but also sustainable in several aspects.

The choice of building materials should be based on the efficient use of renewable and recyclable resources to reduce excesses (Vebry 2008). One of the best ways to achieve this is through the recycling method which has been reported to be a solution to protect the environment from the harmful effects of materials causing pollution such as plastic wastes (Haque 2019). Reports have shown that the average global production of plastic reaches 150 million tons/year (Puri, Mishra, and Jindal 2019) with Indonesia reported to be producing up to 1.6 tons or $80 \%$ of plastic wastes per year (Fajriyanto and Firdaus 2008). Moreover, plastic waste can be used in architecture as alternative materials in concrete mixtures (Rismayasari, Utari, and 
Santosa 2016), eco-bricks (Manisha and Singh 2017; Taaffe et al. 2014), paving blocks (Agyeman, Obeng-Ahenkora, Assiamah, and Twumasi 2019), interlock brick (Bernardi et al. 2017), and several others.

Plastic waste is a global problem due to its non-biodegradability and non-degradability for hundreds of years (Manisha and Singh 2017). Some scientists even reported it lasts for 4,500 years without degradation (D et al. 2014). The accumulation of plastic waste cause problems such as (1) occupying the spaces designed for other wastes, (2) having the tendency to be lifted to the surface when landfilled to pollute the environment, (3) releasing harmful substances when burned, (4) blocking of water flow when scattered in drainages (Sahwan et al. 2005). It is, however, possible to recycle pure plastic materials two to three times due to the reduction in its strength at each recycling process by thermal degradation (Singh et al. 2017). Plastics are considered good because they are not easily broken, not corrosive, weather-resistant (Juhana and Sungkono 2018), flexible, and also resistant to chemicals, water, and impact (D et al. 2014).

This material also has the ability to provide thermal insulation apart from being used as a building component and this reduces the use of electrical energy in cooling a room (Safinia and Alkalbani 2016). It is a good alternative in construction due to its ability to reduce the conductive heat by increasing the thermal insulation of the building walls (Mondal, Bose, and Bansal 2019) as well as to reduce noise (Kurniasari et al. 2019). This is very important considering the tropical climate of Indonesia with quite a hot temperature, thereby, making the selection of plastic waste recycling as an alternative building material and a solution in the architectural field to support sustainability and improve the acoustic and thermal performance of buildings.

This research aimed to determine the innovative interlock brick model previously applied in architecture using recycled plastic waste that supports both acoustic and thermal performance of a building. It also investigated different types and profiles of interlocking bricks, the materials with the characteristics to support the acoustic and thermal performance of buildings, and the methods used in the research.

\section{Method}

A library research method was used in this study and this involved collecting empirical data from previous studies to obtain the best findings. This is considered scientific systematic bibliographic research which includes the collection of bibliographic material related to the research objectives using literature review followed by the organization and presentation of the data obtained (Danandjaja 2014).

Secondary data were obtained from previous studies in the form of books and scientific journals related to the acoustic and thermal performance of buildings based on the use of recycled plastic waste as a component in the interlocking brick. Moreover, similar data were grouped based on the themes and research topics determined by the researchers and arranged according to the order of the year of publication to follow the development of the topic over the years. The data were, therefore, presented in the form of a point table and described using a diagram to clarify the grouping of themes and topics based on the findings from the literature reviewed.

\section{Result and discussion}

Literature review concerning the discussion topics

The studies reviewed were observed to have discussed the following research topics: 
Table 1. Research topics in the literature review

\begin{tabular}{|c|c|c|c|c|c|c|c|c|}
\hline \multirow{3}{*}{ No } & \multirow{3}{*}{ References } & \multicolumn{6}{|c|}{ Study focus } & \multirow{3}{*}{ Point } \\
\hline & & \multicolumn{2}{|c|}{$\begin{array}{c}\text { Innovation of brick } \\
\text { component profile } \\
\text { development }\end{array}$} & \multicolumn{2}{|c|}{$\begin{array}{l}\text { Utilization of plastic waste in } \\
\text { components }\end{array}$} & \multicolumn{2}{|c|}{$\begin{array}{c}\text { Testing components in } \\
\text { supporting space } \\
\text { performance }\end{array}$} & \\
\hline & & $\begin{array}{l}\text { Component } \\
\text { types } \\
\text { determination }\end{array}$ & $\begin{array}{c}\text { Brick } \\
\text { component } \\
\text { assembly } \\
\text { system }\end{array}$ & $\begin{array}{l}\text { Plastic material } \\
\text { types } \\
\text { determination }\end{array}$ & $\begin{array}{c}\text { Material } \\
\text { stress/strength } \\
\text { test }\end{array}$ & $\begin{array}{c}\text { Thermal } \\
\text { resistance/water } \\
\text { absorption } \\
\text { components }\end{array}$ & $\begin{array}{l}\text { Component } \\
\text { acoustic test }\end{array}$ & \\
\hline 1 & $\begin{array}{l}\text { (Fajriyanto and } \\
\text { Firdaus 2008) }\end{array}$ & 1 & & 1 & 1 & & & 3 \\
\hline 2 & (Kintingu 2009) & 1 & 1 & & 1 & & & 3 \\
\hline 3 & $\begin{array}{l}\text { (Huff and } \\
\text { Shouldice 2010) }\end{array}$ & 1 & 1 & & & & & 2 \\
\hline 4 & (Pratikto 2010) & & & 1 & 1 & & & 2 \\
\hline 5 & (Rai et al. 2012) & & & 1 & 1 & & & 2 \\
\hline 6 & (Sina et al., 2012) & & & 1 & 1 & & & 2 \\
\hline 7 & (Deepak 2012) & 1 & 1 & & 1 & & & 3 \\
\hline 8 & $\begin{array}{l}\text { (Kasmudjiastuti } \\
\text { and Yuniari 2012) }\end{array}$ & & & 1 & 1 & 1 & & 3 \\
\hline 9 & $\begin{array}{l}\text { (Arslan and Arslan } \\
\text { 2013) }\end{array}$ & & & & 1 & 1 & 1 & 3 \\
\hline 10 & $\begin{array}{l}\text { (Sinarep, Catur, } \\
\text { and Hafidzul } \\
\text { 2014) }\end{array}$ & & & 1 & & & 1 & 2 \\
\hline 11 & (D et al. 2014) & 1 & & 1 & 1 & & & 3 \\
\hline 12 & (Kurniawan 2014) & & 1 & & & & 1 & 2 \\
\hline 13 & $\begin{array}{l}\text { (Watile, } \\
\text { Deshmukh, and } \\
\text { Muley 2014) }\end{array}$ & 1 & 1 & & & & & 2 \\
\hline 14 & (Taaffe et al. 2014) & 1 & & 1 & 1 & & 1 & 4 \\
\hline 15 & (Aubé et al. 2015) & 1 & 1 & & & & & 2 \\
\hline 16 & $\begin{array}{l}\text { (Jasvi and Bera } \\
\text { 2015) }\end{array}$ & 1 & 1 & & & & & 2 \\
\hline 17 & $\begin{array}{l}\text { (Sommerhuber, } \\
\text { Welling, and } \\
\text { Krause 2015) }\end{array}$ & & & 1 & 1 & & & 2 \\
\hline 18 & $\begin{array}{l}\text { (Sudarmono et al.i, } \\
\text { 2015) }\end{array}$ & 1 & & 1 & 1 & & & 3 \\
\hline 19 & $\begin{array}{l}\text { (Pati, Homma, and } \\
\text { Iki 2015) }\end{array}$ & 1 & & 1 & & & & 2 \\
\hline 20 & $\begin{array}{l}\text { (A. Raut, et al, } \\
\text { 2015) }\end{array}$ & 1 & & 1 & & 1 & & 3 \\
\hline 21 & $\begin{array}{l}\text { (Wahid, Rawi, and } \\
\text { Desa 2015) }\end{array}$ & 1 & & 1 & 1 & 1 & & 4 \\
\hline 22 & $\begin{array}{l}\text { (Ge, Yue, and Sun } \\
\text { 2015) }\end{array}$ & 1 & & 1 & 1 & 1 & & 4 \\
\hline 23 & $\begin{array}{l}\text { (Mansour and Ali } \\
\text { 2015) }\end{array}$ & 1 & & 1 & 1 & 1 & & 4 \\
\hline 24 & (Chen 2016) & 1 & & & 1 & 1 & & 3 \\
\hline 25 & $\begin{array}{l}\text { (Ghofrani, et al, } \\
\text { 2016) }\end{array}$ & 1 & & & & & 1 & 2 \\
\hline 26 & $\begin{array}{l}\text { (Previatti et al. } \\
\text { 2016) }\end{array}$ & 1 & 1 & 1 & 1 & 1 & & 5 \\
\hline 27 & $\begin{array}{l}\text { (Rismayasari, } \\
\text { Utari, and Santosa } \\
\text { 2016) }\end{array}$ & & & 1 & 1 & 1 & & 3 \\
\hline 28 & $\begin{array}{l}\text { (Safinia and } \\
\text { Alkalbani 2016) }\end{array}$ & 1 & & 1 & 1 & & & 3 \\
\hline 29 & $\begin{array}{l}\text { (Said and } \\
\text { Sungkono 2016) }\end{array}$ & 1 & & 1 & 1 & 1 & & 3 \\
\hline 30 & (Satito 2016) & 1 & & 1 & & 1 & & 3 \\
\hline 31 & $\begin{array}{l}\text { (Muyen, Barna, } \\
\text { and Hoque 2016) }\end{array}$ & 1 & 1 & 1 & 1 & & & 4 \\
\hline
\end{tabular}




\begin{tabular}{|c|c|c|c|c|c|c|c|c|}
\hline \multirow{3}{*}{ No } & \multirow{3}{*}{ References } & \multicolumn{6}{|c|}{ Study focus } & \multirow{3}{*}{ Poin } \\
\hline & & \multicolumn{2}{|c|}{$\begin{array}{c}\text { Innovation of brick } \\
\text { component profile } \\
\text { development }\end{array}$} & \multicolumn{2}{|c|}{$\begin{array}{l}\text { Utilization of plastic waste in } \\
\text { components }\end{array}$} & \multicolumn{2}{|c|}{$\begin{array}{c}\text { Testing components in } \\
\text { supporting space } \\
\text { performance }\end{array}$} & \\
\hline & & $\begin{array}{c}\text { Component } \\
\text { types } \\
\text { determination }\end{array}$ & $\begin{array}{c}\text { Brick } \\
\text { component } \\
\text { assembly } \\
\text { system } \\
\end{array}$ & $\begin{array}{l}\text { Plastic material } \\
\text { types } \\
\text { determination }\end{array}$ & $\begin{array}{c}\text { Material } \\
\text { stress/strength } \\
\text { test }\end{array}$ & $\begin{array}{c}\text { Thermal } \\
\text { resistance/water } \\
\text { absorption } \\
\text { components }\end{array}$ & $\begin{array}{l}\text { Component } \\
\text { acoustic test }\end{array}$ & \\
\hline 32 & $\begin{array}{l}\text { (B. Shanmugavalli, } \\
\text { et al, 2017) }\end{array}$ & & & 1 & 1 & & & 2 \\
\hline 33 & $\begin{array}{l}\text { (Martins et al., } \\
\text { 2017) }\end{array}$ & & & 1 & & 1 & & 2 \\
\hline 34 & (Pramitasari 2017) & 1 & & & & 1 & & 2 \\
\hline 35 & $\begin{array}{l}\text { (Wariyatno, } \\
\text { Haryanto, and } \\
\text { Sumiyanto 2017) }\end{array}$ & 1 & 1 & & & & & 2 \\
\hline 36 & $\begin{array}{l}\text { (Antico et al. } \\
2017 \text { ) }\end{array}$ & 1 & & 1 & 1 & 1 & & 3 \\
\hline 37 & $\begin{array}{l}\text { (Bernardi et al. } \\
\text { 2017) }\end{array}$ & 1 & 1 & 1 & & & & 3 \\
\hline 38 & $\begin{array}{l}\text { (Manisha and } \\
\text { Singh 2017) }\end{array}$ & 1 & & 1 & 1 & 1 & & 4 \\
\hline 39 & $\begin{array}{l}\text { (Muttaqim and } \\
\text { Anggono 2017) }\end{array}$ & & & 1 & 1 & 1 & & 3 \\
\hline 40 & $\begin{array}{l}\text { (Purwanto and } \\
\text { Darmawan 2017) }\end{array}$ & 1 & 1 & 1 & 1 & & & 4 \\
\hline 41 & $\begin{array}{l}\text { (Susilawati and } \\
\text { Tyas 2018) }\end{array}$ & 1 & 1 & & & & & 2 \\
\hline 42 & $\begin{array}{l}\text { (Mageswari, } \\
\text { Chiranjeevi, and } \\
\text { Magesh 2018) }\end{array}$ & 1 & & 1 & 1 & 1 & & 4 \\
\hline 43 & $\begin{array}{l}\text { (Mufika, Dewi, } \\
\text { and Arifi 2018) }\end{array}$ & 1 & & 1 & 1 & & & 3 \\
\hline 44 & $\begin{array}{l}\text { (Sukhwal et al. } \\
2018 \text { ) }\end{array}$ & 1 & & 1 & 1 & & & 3 \\
\hline 45 & (Patil et al. 2018) & 1 & & 1 & 1 & & & 3 \\
\hline 46 & $\begin{array}{l}\text { (Maowa and } \\
\text { Rashid 2018) }\end{array}$ & 1 & & 1 & 1 & & & 3 \\
\hline 47 & $\begin{array}{l}\text { (Sormunen and } \\
\text { Kärki 2019) }\end{array}$ & 1 & & 1 & & 1 & & 3 \\
\hline 48 & $\begin{array}{l}\text { (Ni`mah, et al, } \\
\text { 2019) }\end{array}$ & & & 1 & 1 & & & 2 \\
\hline 49 & $\begin{array}{l}\text { (Agyeman et al. } \\
\text { 2019) }\end{array}$ & & & 1 & 1 & & & 2 \\
\hline 50 & $\begin{array}{l}\text { (Nugroho et al. } \\
\text { 2019) }\end{array}$ & 1 & & 1 & & 1 & & 3 \\
\hline 51 & (Amir et al. 2019) & 1 & & 1 & & & & 2 \\
\hline 52 & (Hakim 2019) & & & 1 & 1 & 1 & & 3 \\
\hline 53 & $\begin{array}{l}\text { (Rahmadiny et al. } \\
\text { 2019) }\end{array}$ & & & 1 & 1 & & & 2 \\
\hline 54 & $\begin{array}{l}\text { (Kurniasari et al. } \\
2019 \text { ) }\end{array}$ & & & 1 & & & 1 & 2 \\
\hline 55 & (Amijaya 2019) & & & 1 & 1 & & & 2 \\
\hline 56 & (Asriza et al. 2019) & & & 1 & & 1 & & 2 \\
\hline 57 & $\begin{array}{l}\text { (Chaurasia and } \\
\text { Gangwar 2019) }\end{array}$ & 1 & & 1 & 1 & 1 & & 4 \\
\hline 58 & $\begin{array}{l}\text { Bhushaiah, } \\
\text { Mohammad, and } \\
\text { Rao 2019) }\end{array}$ & 1 & & 1 & 1 & 1 & & 4 \\
\hline 59 & $\begin{array}{l}\text { (Intan and Santosa } \\
\text { 2019) }\end{array}$ & 1 & & 1 & 1 & 1 & & 4 \\
\hline 60 & $\begin{array}{l}\text { (Awoyera and } \\
\text { Adesina 2020) }\end{array}$ & 1 & & 1 & & & & 2 \\
\hline 61 & $\begin{array}{l}\text { (Dewangan et al. } \\
2020 \text { ) }\end{array}$ & 1 & & & & & & 1 \\
\hline
\end{tabular}




\begin{tabular}{|c|c|c|c|c|c|c|c|c|}
\hline \multirow{3}{*}{ No } & \multirow{3}{*}{ References } & \multicolumn{6}{|c|}{ Study focus } & \multirow{3}{*}{ Poin } \\
\hline & & \multicolumn{2}{|c|}{$\begin{array}{c}\text { Innovation of brick } \\
\text { component profile } \\
\text { development }\end{array}$} & \multicolumn{2}{|c|}{$\begin{array}{c}\text { Utilization of plastic waste in } \\
\text { components }\end{array}$} & \multicolumn{2}{|c|}{$\begin{array}{l}\text { Testing components in } \\
\text { supporting space } \\
\text { performance }\end{array}$} & \\
\hline & & $\begin{array}{l}\text { Component } \\
\text { types } \\
\text { determination }\end{array}$ & $\begin{array}{c}\text { Brick } \\
\text { component } \\
\text { assembly } \\
\text { system } \\
\end{array}$ & $\begin{array}{c}\text { Plastic material } \\
\text { types } \\
\text { determination }\end{array}$ & $\begin{array}{c}\text { Material } \\
\text { stress/strength } \\
\text { test }\end{array}$ & $\begin{array}{c}\text { Thermal } \\
\text { resistance/water } \\
\text { absorption } \\
\text { components }\end{array}$ & $\begin{array}{l}\text { Component } \\
\text { acoustic test }\end{array}$ & \\
\hline 62 & $\begin{array}{l}\text { (Widyawati and } \\
\text { Haqqi 2020) }\end{array}$ & 1 & & 1 & 1 & & & 3 \\
\hline 63 & $\begin{array}{l}\text { (Sultan, et al., } \\
2020)\end{array}$ & 1 & & 1 & 1 & & & 3 \\
\hline 64 & $\begin{array}{l}\text { (Sultan, Jaiswal, } \\
\text { Jaiswal, Sahu, } \\
\text { Devannand, et al. } \\
\text { 2020) }\end{array}$ & 1 & & 1 & 1 & & & 3 \\
\hline & $\begin{array}{l}\text { evious studies in } \\
\text { cordance with the } \\
\text { earch parameters }\end{array}$ & 45 & 13 & 50 & 42 & 24 & 6 & \\
\hline
\end{tabular}

A study usually discusses one to five predefined parameters and this means there is a need to trace the studies to obtain points on each parameter and determine the literature in line with the objectives of this research.

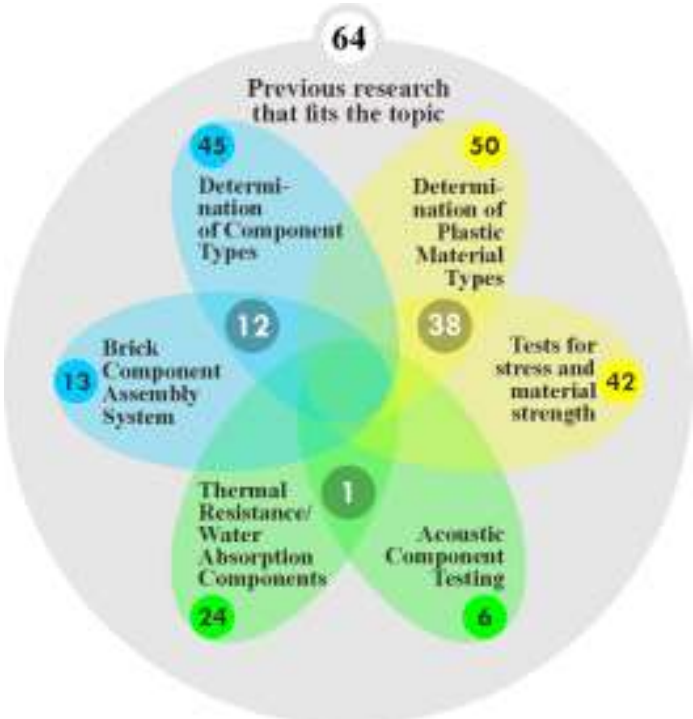

Figure 1. Diagram of variables and parameter findings from the literature study
The literature reviewed showed 64 studies discuss the same topic as this research. It was also discovered that the parameters used in determining the type of components for buildings were discussed in 45 studies while brick component assembly systems were discussed in 13 studies and both concepts were discussed in 12 studies. Moreover, the parameters to determine the types of plastic materials to be used were discussed in 50 studies while the material stress/strength test was in 42 studies and both concepts were discussed in 38 studies. It was also observed that the parameters of thermal resistance/water absorption of components were discussed in 24 studies while the acoustic test of components was discussed in 6 studies and only 1 study discussed both concepts. 


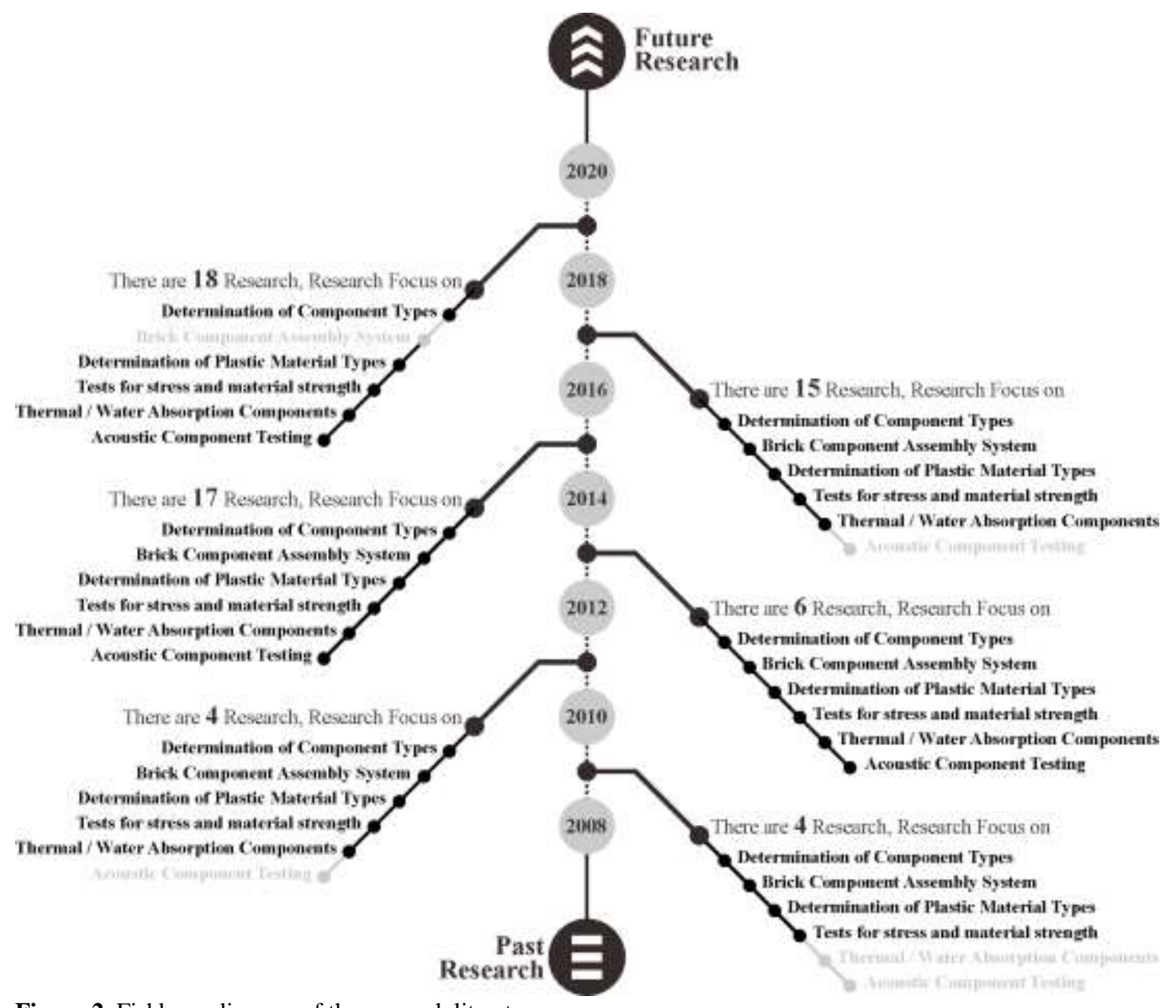

Figure 2. Fishbone diagram of the research literature

Figure 2 shows the number and focus of research in each year and 4 studies were observed to have discussed four research parameters in 2008-2010, 4 studies with thermal parameters added in 2011-2012, all parameters were discussed in 2013-2016 but there was no discussion of thermal parameters in 2017-2018, and brick assembly system was not discussed anymore in 2019-2020.

Review of the methods used

The method used is based on the focus of each study as described by the data collected and some of them include:

a. Theoretical modeling methods supported by simulation designs and drawings

b. Laboratory experimental methods

c. Simulation experimental methods

d. Methods of literature and secondary data

e. Quantitative method using a scientific paradigm f. Qualitative methods in gaining the advantages of the development system

Review of analysis related to indicators in research parameters

A. Component Types Determination

Analysis of 65 studies on the parameters for determining the type of component showed only 7 of them met the specifications which is the use of interlock brick components in constructing walls.

B. Brick component assembly system

Analysis of 13 studies which discuss the parameters of brick component assembly systems showed 2 met the specifications which involve the use of the pin-pin assembly system which does not require adhesive media. 
C. Plastic material types determination

Analysis of 50 studies which discuss the parameters of the type of plastic material showed only 10 met the specifications which involve using plastic and waste materials with light density and processed by heating.

\section{Material stress/strength test}

The material stress/strength test parameters were analyzed using the test model to produce compressive strength in line with the standard required for wall construction with the density value recorded to be between $240-800 \mathrm{~kg} / \mathrm{m}^{3}$ while the compressive strength was between 0.35 - $7 \mathrm{MPa}$ (Widiantoro and Ma'arif 2014). It was discovered that 23 out of the 42 studies analyzed discussed the material stress/strength test.
E. Thermal resistance/water absorption components

Analysis of 24 studies which discuss the test parameters of thermal resistance/water absorption components showed only 10 met the specifications by using plastic-based waste materials considered to be superior to conventional materials.

\section{F. Acoustic component test}

Analysis of 6 studies which discussed the acoustic component parameters showed only 3 met the specifications by using plastic-based waste materials considered to be superior to conventional materials.

The studies were selected using two indicators with predetermined criteria for each parameter and those filtered from the analysis results are presented in the following figure 3 .

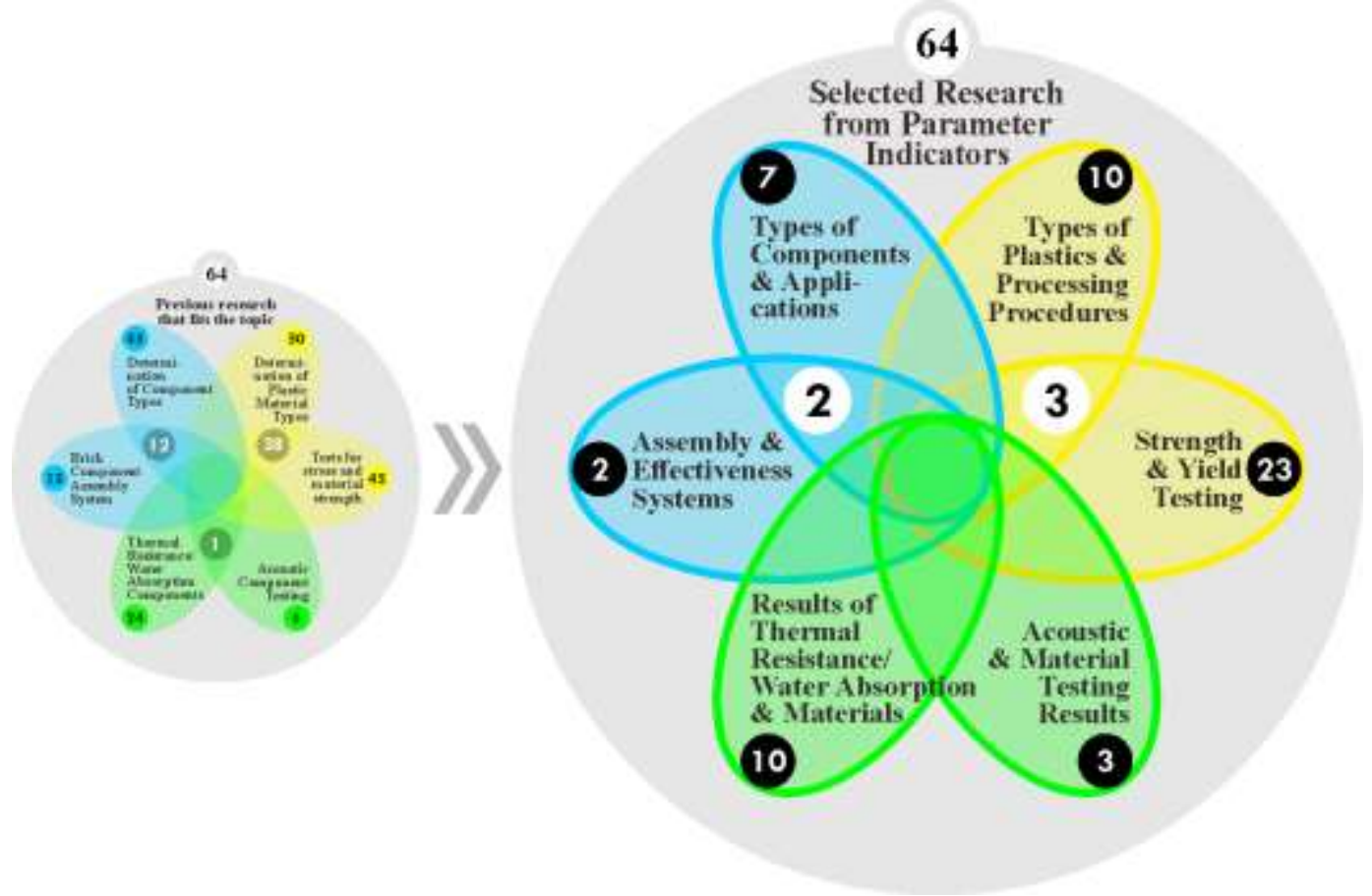

Figure 3. The selected study screening diagram based on parameter indicators

This screening was conducted to narrow the findings in order to determine the studies considered relevant to the research topic and theme.
Authenticity in literature achievement

Each study was summarized based on the method and purpose as well as the discussions related to the parameters in this research after which the findings were compiled in Microsoft Excel to indicate the authenticity of the secondary data obtained. 


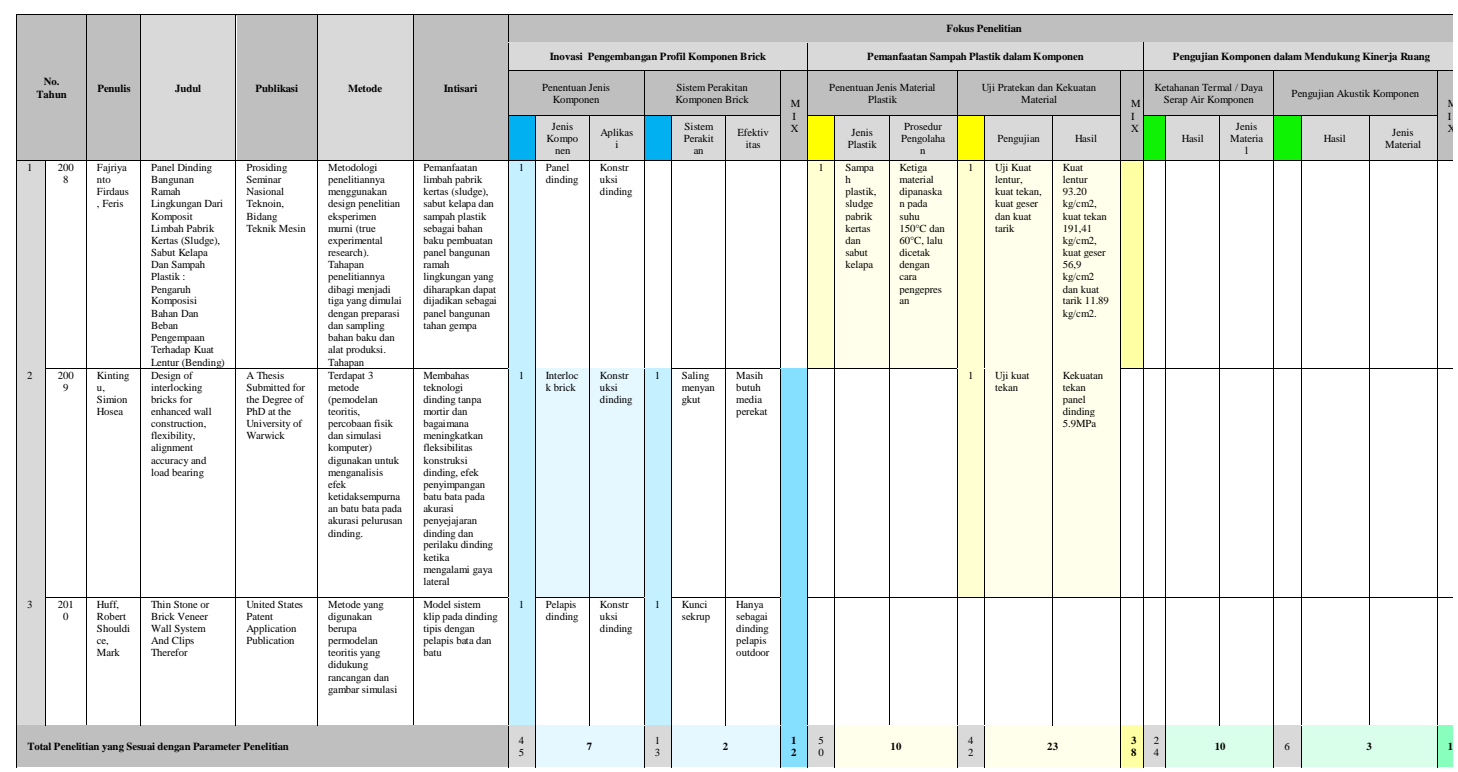

Figure 4. Arrangement of library data in Microsoft Excel

The data presented showed the title, year of publication, author, publication, method, the essence of the study, and the parameter points discussed.

Relationship between the selected parameters

The studies observed to have discussed the six parameters determined in each indicator were selected according to the specified specifications and later linked to this research to find a match to produce a valid object of study which is in the form of an interlock brick component produced from recycled plastic waste which supports the acoustic and thermal performance of a building. The stages used in this process are as follows: a. Ensuring a study was selected on the parameters to determine the type of plastic material and the material stress/strength test.

b. The fulfillment of point (a) led to the collaboration of the existing components with the interlock brick design used in the study selected on the types of the component and assembly system.

c. In order to support the thermal/water absorption and acoustic performance of the components, the parameter indicator was applied as a coating material or secondary skin to the interlock brick component.

This linking process, however, determined the superiority of the component according to the parameters selected in the predetermined model.

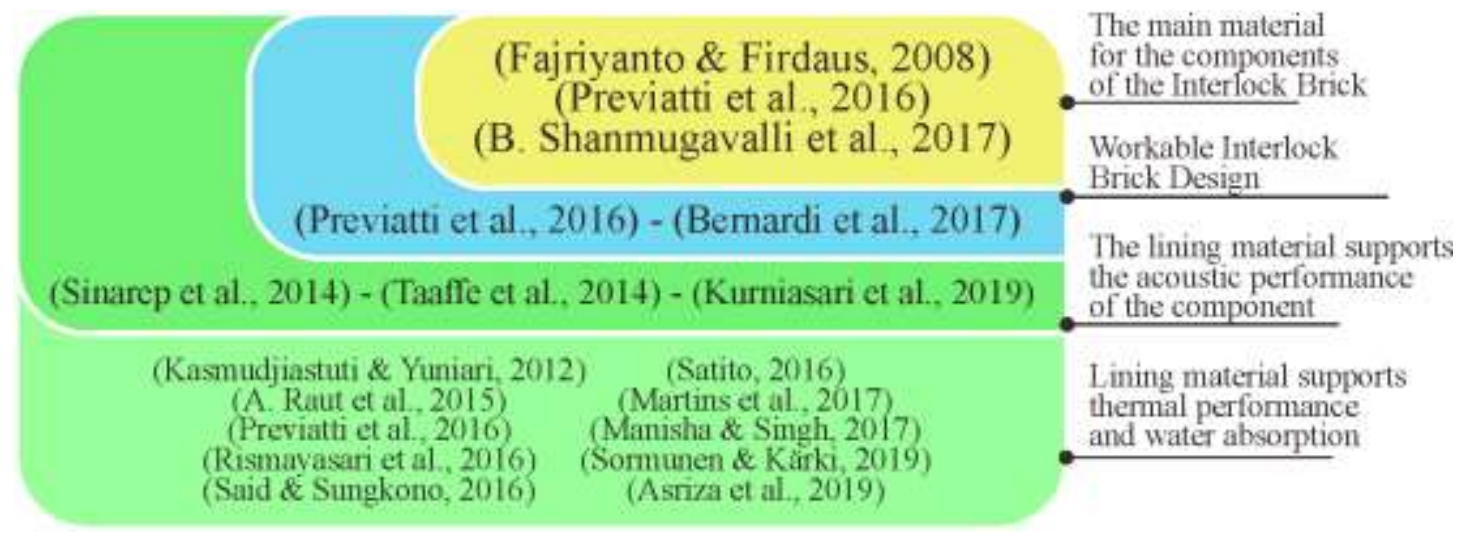

Figure 5. Model linking research stage 
This linking model is expected to serve as a reference for the production of an interlock brick component using recycled plastic waste with the capacity to support acoustic and thermal performance in buildings.

\section{Conclusion}

The following conclusions were obtained from the analysis conducted: (a)There are already quite a lot of studies on building components made from plastic waste as well as the application of the material in interlock bricks but there is none on the acoustic and thermal performance of buildings. Therefore, further studies need to test room performance based on the acoustic and thermal aspects of a building constructed using interlock bricks made with recycled plastic wastes;

(b) The variables formulated in this research were divided into three aspects and each was further split into two parameters as shown in table 1; (c) The methods used in the studies reviewed include modeling, laboratory experiment or simulation, literature review as well as quantitative and qualitative analyses; (d) The research linkage model to determine the design compositions required to design interlock bricks produced from recycled plastic waste and with the ability to support the acoustic and thermal performance of a building was produced from this study; (e) The library data collected showed 3 studies can be used as a reference for material composition, 2 studies for interlock brick designs, 3 studies for coating materials to support room acoustics, and 10 studies for coating materials to support thermal comfort of buildings.

The authenticity of the recommended studies can, however, be traced through the contents section of the bibliography.

The findings from this literature review can be used as a guideline for further research on determining the components required for the design of interlock bricks from recycled plastic waste with the ability to support the acoustic and thermal performance of buildings.

\section{References}

Agyeman, S., N. K. Obeng-Ahenkora, S. Assiamah, and G. Twumasi. 2019. 'Exploiting
Recycled Plastic Waste as an Alternative Binder for Paving Blocks Production'. Case Studies in Construction Materials 11: e00246. https://doi.org/10.1016/j.cscm.2019.e00246.

Al-Fakih, Amin, Bashar S Mohammed, Fadhil Nuruddin, and Ehsan Nikbakht. 2018. 'Development of Interlocking Masonry Bricks and Its' Structural Behaviour: A Review Paper'. IOP Conference Series: Earth and Environmental Science 140 (April): 012127. https://doi.org/10.1088/17551315/140/1/012127.

Amijaya, Sita Yuliastuti. 2019. 'Rekayasa Material Plastik Banner Untuk Teknologi Kulit Bangunan (Secondary Facade)'. Media Matrasain 16 (1): 41-47.

Amir, Mardiana, Rita Irmawaty, Muralia Hustim, and Irwan Ridwan Rahim. 2019. 'Material Konstruksi Dinding Yang Terbuat Dari Pengembangan Komposit Plastik Dan Serat Kenaf Serta Serat Glass'. Prosiding Konferensi Nasional Pascasarjana Teknik Sipil (KNPTS), no. November: 393-405.

Antico, Federico C., María J. Wiener, Gerardo Araya-Letelier, and Raúl Gonzalez Retamal. 2017. 'Eco-Bricks: A Sustainable Substitute for Construction Materials'. Revista de La Construccion $\quad 16 \quad$ (3): 518-26. https://doi.org/10.7764/RDLC.16.3.518.

Arslan, M. Hakan, and H. Derya Arslan. 2013. 'Use of Plastic Material for Providing Thermal And Acoustics Comforts in Residence Constructed with RC Tunnel Form System'. CESB (Central Europe Towards Sustainable Building), 301-4. https://doi.org/10.12739/nwsaes.v6i4.500006 6927.g5000062294.

Asriza, Ristika Oktavia, Diah Humaira, Sri Hawa Thu Insan, and Zomi. 2019. 'Sintesis Material Komposit Sampah Plastik Dengan Serbuk Kayu Pelawan (Tristaniopsis Merguensis)'. Prosiding Seminar Nasional Penelitian \& Pengabdian Pada Masyarakat 3: 2-5. https://doi.org/https://doi.org/10.33019/snpp m.v3i0.1357.

Aubé, Stéphane, Bertin Castonguay, Robert Daoust, and Marcel Thomassen. 2015. 'Wall with Decorative Facing'. United States Patent.

Awoyera, P. O., and A. Adesina. 2020. 'Plastic Wastes to Construction Products: Status, Limitations and Future Perspective'. Case 
Studies in Construction Materials 12: e00330. https://doi.org/10.1016/j.cscm.2020.e00330.

B. Shanmugavalli, K. Gowtham, P. Jeba Nalwin, and B. Eswara Moorthy. 2017. 'Reuse of Plastic Waste in Paver Blocks'. International Journal of Engineering Research And V6 (02):

313-15. https://doi.org/10.17577/ijertv6is020162.

Bernardi, Lisa, Pedro Gaspar, Javier Ozcoidi, and Manon Randé. 2017. 'Ecobuild: Plastic Bricks for Sustainable Housing'. Repositori Universitas Pompeu Fabra, 1-60.

Bhushaiah, Rajarapu, Shaik Mohammad, and D Srinivasa Rao. 2019. 'Study of Plastic Bricks Made From Waste Plastic'. IRJET (International Research Journal of Engineering and Technology) 6 (4): 1122.

Chaurasia, Atul, and Sumit Gangwar. 2019. 'Reuse of Plastic Bottles as a Construction Material'. IJETR (International Journal of Engineering and Technical Research) 0869 (9).

Chen, Kuo Wei. 2016. 'Lightweight Brick by Carbon Ash from the Mixed Plastic Waste Treatment Plant'. MATEC Web of Conferences 67. https://doi.org/10.1051/matecconf/20166707 025.

D, Maneeth P, Pramod K, Kishor Kumar, and Shanmukha Shetty. 2014. 'Utilization Of Waste Plastic In Manufacturing Of PlasticSoil Bricks'. IJERT (International Journal of Engineering Research \& Technology) 3 (8): 102.

Danandjaja, James. 2014. "Metode Penelitian Kepustakaan." Antropologi Indonesia. https://doi.org/10.7454/ai.v0i52.3318.

Deepak, Bansal. 2012. 'Sustainable Dry Interlocking Block Masonry Construction'. International Brick and Block Masonry Conference. Brazil, 1-11.

Dewangan, Dolly, Pradeep Kumar, Kamini Rathore, Krishna Dwivedi, Avinash Chatuevedi, and Ashutosh Dwivedi. 2020. 'Utilization of Plastic Waste in Manufacturing of Plastic Sand Bricks'. IJIES (International Journal of Innovations in Engineering and Science) 5 (6): 4.

Fajriyanto, and Feris Firdaus. 2008. 'Panel Dinding Bangunan Ramah Lingkungan Dari Komposit Limbah Pabrik Kertas (Sludge), Sabut Kelapa Dan Sampah Plastik : Pengaruh Komposisi Bahan Dan Beban Pengempaan Terhadap Kuat Lentur (Bending)'. Prosiding
Seminar Nasional Teknoin, Bidang Teknik Mesin, no. January: 55-62.

Ge, Zhi, Hongya Yue, and Renjuan Sun. 2015. 'Properties of Mortar Produced with Recycled Clay Brick Aggregate and PET'. Construction and Building Materials 93: 851-56. https://doi.org/10.1016/j.conbuildmat.2015.0 5.081 .

Ghofrani, Mohammad, Alireza Ashori, Mohammad Hadi Rezvani, and Farzad Arbabi Ghamsari. 2016. 'Acoustical Properties of Plywood/Waste Tire Rubber Composite Panels'. Measurement: Journal of the International Measurement Confederation 94: 382-87.

https://doi.org/10.1016/j.measurement.2016.0 8.020 .

Hakim, Fadhil Ammar. 2019. 'Pemanfaatan Bijih Plastik Jenis High Density Polyethylene (HDPE) Sebagai Subtitusi Agregat Pada Bata Beton (Paving Block)'. Dspace UII, 1-11.

Haque, Md Sazzadul. 2019. "Sustainable Use of Plastic Brick from Waste PET Plastic Bottle as Building Block in Rohingya Refugee Camp: A Review." Environmental Science and Pollution Research 26 (36): 36163-83. https://doi.org/10.1007/s11356-019-06843-y.

Huff, Robert, and Mark Shouldice. 2010. 'Thin Stone or Brick Veneer Wall System And Clips Therefor'. United States Patent Application Publication.

Intan, Syarifah Keumala, and Sandra Santosa. 2019. 'Utilization of PTE and LDPE Plastic Waste and Building Material Waste as Bricks'. Korean Journal of Materials Research 29 (10): 603-8. https://doi.org/10.3740/MRSK.2019.29.10.60 3.

Jasvi, Ali Haider, and D.K. Bera. 2015. 'Sustainable Use of Low Cost Building Materials in the Rural India'. IJRET (International Journal of Research in Engineering and Technology) 04 (25): 53477. https://doi.org/10.15623/ijret.2015.0425077.

Juhana, and Sungkono. 2018. "Panel Plastik Bertulang Hemat Energi." Jurnal Lingkungan Binaan Indonesia 7 (1): 54-59. https://doi.org/10.32315/jlbi.7.1.54.

Kasmudjiastuti, Emiliana, and Arum Yuniari. 2012. 'Pengaruh Filler PCC (Precipitated Calcium Carbonate) Terhadap Sifat Mekanik, Elektrik, Termal Dan Morfologi Dari Komposit HDPE/PCC'. Majalah Kulit, Karet, 
Dan Plastik $28 \quad$ (1): 35. https://doi.org/10.20543/mkkp.v28i1.203.

Kintingu, Simion Hosea. 2009. 'Design of Interlocking Bricks for Enhanced Wall Construction, Flexibility, Alignment Accuracy and Load Bearing'. A Thesis Submitted for the Degree of PhD at the University of Warwick.

Kurniasari, Angela Evita, Nadya Swastikirana, Ociani Sry Pabinti, and Patricia P. Noviandri. 2019. 'Pengolahan Limbah Plastik Sebagai Material Alternatif Akustik Ruang'. SMART (Seminar on Architecture Research \& Technology) 4 (1): 19-30.

Kurniawan, Oki. 2014. 'Studi Penanganan Kebisingan Untuk Memperbaiki Kualitas Akustik Ruang Kelas Melalui Pemanfaatan Sampah Kotak Karton Gelombang'. https://doi.org/10.13140/RG.2.2.10517.42727

Mageswari, Dr.M., J.S. Chiranjeevi, and K. Magesh. 2018. 'Plastic Bricks'. IRJAET (International Research Journal in Advanced Engineering and Technology) 4 (2): 3167-72.

Manisha, and Navinderdeep Singh. 2017. 'Investigating Strength and Properties of Ecoladrillo: Eco Bricks'. International Journal of Civil Engineering and Technology 8 (7): 134-42.

Mansour, Ashraf Mansour Habib, and Subhi A. Ali. 2015. 'Reusing Waste Plastic Bottles as an Alternative Sustainable Building Material'. Energy for Sustainable Development 24: 7985. https://doi.org/10.1016/j.esd.2014.11.001.

Maowa, Jannatul, and Muhammad Harunur Rashid. 2018. Utilization of Waste Plastic in Manufacturing of Brick. International Energy \& Engineering Congress.

Martins, G., F. Antunes, A. Mateus, and C. Malça. 2017. 'Optimization of a Wood Plastic Composite for Architectural Applications'. Procedia Manufacturing 12 (December 2016): 203-20. https://doi.org/10.1016/j.promfg.2017.08.025

Mondal, M. K., B. P. Bose, and P. Bansal. 2019. "Recycling Waste Thermoplastic for Energy Efficient Construction Materials: An Experimental Investigation." Journal of Environmental Management 240 (May 2018): 119-25. https://doi.org/10.1016/j.jenvman.2019.03.01 6.

Mufika, Neyla Rohmah, Sri Murni Dewi, and Eva Arifi. 2018. 'The Effect of Plastic Concrete Use on Lightweight Hollow Concrete Brick against Compressive Strength and Flexure Strength With Variations of Fiber Yarn'. Jurnal Mahasiswa Jurusan Teknik Sipil 1 (2).

Muttaqim, Zaennal, and Agus Dwi Anggono. 2017. 'Pengaruh Variasi Komposisi Antara Limbah Plastik High Density Polyethylene (HDPE) Dan Abu Dasar Batubara Sebagai Material Komposit Dengan Matrik Semen Terhadap Kekuatan Tekan Dan Serapan Air'. Karya Ilmiah Universitas Muhammadiyah Surakarta.

Muyen, Z, TN Barna, and MN Hoque. 2016. 'Strength Properties of Plastic Bottle Bricks and Their Suitability as Construction Materials in Bangladesh'. Progressive Agriculture $\quad 3 \quad$ (27): $\quad 362-68$ https://doi.org/https://doi.org/10.3329/pa.v27i 3.30833 .

Nìmah, Lailan, Isna Syauqiah, Agus Mirwan, Doni Rahmat Wicakso, and Hesti Wijayanti. 2019. 'Batako Dari Limbah Botol Plastik: Tinjauan Kuat Tekan'. Al Ulum Sains Dan Teknologi 5 (1): 26-29.

Nugroho, Samsu Adi, Muhammad Dikri Fadilah, Thesalonika Br Ginting, and Asri Nurdiana. 2019. 'Hexalock Brick: Inovasi Batako Pendukung Konsep Pre-Febricate Building Yang Ringan, Ekonomis Dan Ramah Lingkungan'. Jurnal Proyek Teknik Sipil 2 (1): 25-30.

Pati, Dibya Jivan, Riken Homma, and Kazuhisa Iki. 2015. 'Plastic Bottle Masonry as Alternate Solution to Housing Problems in Urban Areas of India'. Applied Sciences, Engineering \& Technology, no. October.

Patil, Ushadevi, Dheeraj Chavan, Yogesh Rai, Rushikesh Surwase, Tejas B Thombare, Sujit B Patil, and Akshay Shinde. 2018. 'Utilization of Waste PET Bottles and Brick Kiln Dust as Construction Material for Low Cost Housing'. International Journal of Research in Engineering, Science and Management 1 (6): 13-15.

Pradono, Budi. 2019. 'The Interiority of Proximity Between Nature and Architecture in Contemporary and Tropically Context with Cases Studies'. ARTEKS: Jurnal Teknik 
Arsitektur $3 \quad$ (2): $\quad 129-44$. https://doi.org/10.30822/arteks.v3i2.63.

Pramitasari, Putri Herlia. 2017. 'Panel Dinding Berventilasi (Breathing Wall) Pada Selubung Bangunan Di Daerah Beriklim Tropis Lembab'. Spectra XV (29): 1-12.

Prastyatama, Budianastas, and Anastasia Maurina. 2018. 'Kinerja Struktural Interlocking Compressed Earth Block (ICEB) Dengan Serta Ijuk Sebagai Stabilisator'. ARTEKS : Jurnal Teknik Arsitektur 3 (1): 27 36. https://doi.org/10.30822/arteks.v3i1.51.

Pratikto. 2010. 'Beton Ringan Ber-Agregat Limbah Botol Plastik Jenis PET (Poly Ethylene Terephthalate)'. Jurnal Rekayasa Sipil 9 (1): 1-8.

Previatti, Bruna, Carolina Werlang Fazenda, Fernanda dos Santos Machry, and Rafaela Diehl Milani. 2016. 'Análise de Implantação de Uma Residência Sustentável Em Passo Fundo - BR'. Seminario Internacional de Construcoes Sustentaveis, no. 1.

Puri, Hardeep S, Durga Shanker Mishra, and V. K. Jindal. 2019. "Plastic Waste Management Issues, Solutions and Case Studies." In Ministry of Housing \& Urban Affairs GovernMent of India, 105-13. https://doi.org/10.1201/9780429059247-7.

Purwanto, and Darmawan. 2017. 'Modelling of Plastic Waste as an Alternative Building Material in the Form of Bricks'. IJAEMR (International Journal of Advanced Engineering and Management Research) 2 (3): 748-54.

Rahmadiny, Arinda, Novadh Bargreitha, Tommy Anggiawan Putra Pamungkas, Ricky Rialdi Chandra, Mohamed Angky, and Agustinus Agus Setiawan. 2019. 'Penggunaan Material Limbah High Density Polyetylene (HDPE) Sebagai Bahan Pengganti Agregat Kasar Pada Campuran Beton'. Widyakala Journal 6: 6. https://doi.org/10.36262/widyakala.v6i0.161.

Rai, Baboo, S. Tabin Rushad, Bhavesh Kr, and S. K. Duggal. 2012. 'Study of Waste Plastic Mix Concrete with Plasticizer'. ISRN Civil Engineering 2012: 1-5. https://doi.org/10.5402/2012/469272.

Raut, Aditya, Mohammad Salman Patel, Nilesh B. Jadhwar, Uzair Khan, and Sagar W. Dhengare. 2015. 'Investigating the Application of Waste Plastic Bottle as a Construction Material'. Journal of Advance
Research in Mechanical and Civil Engineering 2 (3): 86-99.

Rismayasari, Yessi, Utari, and Usman Santosa. 2016. 'Pembuatan Beton Dengan Campuran Limbah Plastik Dan Karakterisasinya'. Indonesian Journal of Applied Physics 2 (02): 24. https://doi.org/10.13057/ijap.v2i02.1284.

Safinia, Sina, and Amani Alkalbani. 2016. 'Use of Recycled Plastic Water Bottles in Concrete Blocks'. Procedia Engineering 164 (June): 214-21. https://doi.org/10.1016/j.proeng.2016.11.612.

Sahwan, Firman L, Djoko Heru Martono, Sri Wahyono, and Lies A Wisoyodharmo. 2005. "Sistem Pengelolaan Limbah Plastik Di Indonesia." Jurnal Sistem Pengolahan Limbah J. Tek. Ling. P3TL-BPPT 6 (1): 31118.

Said, Juhana, and Sungkono. 2016. 'Pengolahan Sampah Plastik Dan Tanaman Enceng Gondok Menjadi Bahan Bangunan Alternatif Hemat Energi'. Prosiding Temu Ilmiah IPLBI, no. 1: 187-92.

Satito, Aryo. 2016. 'Rancang Bangun Mesin Wood Plastic Composite Screw Extrussion Molding (Bagian Dari Prototipe Unit Produksi Panel Komposit Kayu Plastik Untuk Dinding Dan Lantai)'. Prosiding SENTRINOV (Seminar Nasional Terapan Riset Inovatif) 01: 15-16.

Sina, Dantje A. T., I Made Udiana, and Bernad D. Da Costa. 2012. 'Pengaruh Penambahan Cacahan Limbah Plastik Jenis High Density Polyethylene (HDPE) Pada Kuat Lentur Beton'. Jurnal Teknik Sipil 1 (4).

Sinarep, S., Agus Dwi Catur, and M. Hafidzul. 2014. 'Redaman Suara Pada Komposit Sandwich Polyester Berpenguat Serat Sisal Dengan Core Styrofoam'. Dinamika Teknik Mesin 4 (1): 30-37. https://doi.org/10.29303/d.v4i1.67.

Singh, Narinder, David Hui, Rupinder Singh, I. P.S. Ahuja, Luciano Feo, and Fernando Fraternali. 2017. "Recycling of Plastic Solid Waste: A State of Art Review and Future Applications." Composites Part B: Engineering 115: 409-22. https://doi.org/10.1016/j.compositesb.2016.0 9.013.

Sommerhuber, Philipp F., Johannes Welling, and Andreas Krause. 2015. 'Substitution Potentials of Recycled HDPE and Wood Particles from Post-Consumer Packaging Waste in Wood-Plastic Composites'. Waste 
Management 46: 76-85. https://doi.org/10.1016/j.wasman.2015.09.01 1.

Sormunen, Petri, and Timo Kärki. 2019. 'Recycled Construction and Demolition Waste as a Possible Source of Materials for Composite Manufacturing'. Journal of Building Engineering 24 (August 2018): 100742. https://doi.org/10.1016/j.jobe.2019.100742.

Sudarmono, Karnawan Joko Setiono, and Dianita Ratna Kusumastuti. 2015. 'Waste Plastic Bags For Cheap Houses Mixed Concrete Solutions'. Prosiding Sentrinov (Seminar Nasional Terapan Riset Inovatif) 001: 24772097.

Sukhwal, Sandeep, Manish Gautam, Bhaskar Jangid, and MD Parwez Musharraf. 2018. 'Utilization of Waste Material for Manufacturing of Bricks'. Journal of Basic and Applied Engineering Research 5 (2): 103 5.

Sultan, Mohammad, Rahul Jaiswal, Roshan Jaiswal, Falgunee Ram Sahu, Devanand, and Pradeep Nirmal. 2020. 'Use of Plastic Waste in Civil Constructions and Innovative Decorative Material'. IJIES (International Journal of Innovations in Engineering and Science) $\quad 3 \quad$ (5): $11-15$. https://doi.org/10.15406/mojce.2017.03.0008 2.

Sultan, Mohammad, Rahul Jaiswal, Roshan Jaiswal, Falgunee Ram Sahu, Devannand, and Megha Sahu. 2020. 'Utilization of Plastic Waste in Manufacturing of Plastic Sand Bricks'. IJIES (International Journal of Innovations in Engineering and Science) 5 (1).

Susilawati, and Indah Wahyuning Tyas. 2018. 'Lock-Brick System for Sustainable and Environment Infrastructure Building Materials'. IOP Conference Series: Materials Science and Engineering 371 https://doi.org/10.1088/1757899X/371/1/012016.

https://doi.org/10.1016/j.matdes.2014.03.045

Vebry, Muammar. 2008. "Penggunaan Bahan Bangunan Yang Berkelanjutan Dalam Proses Rekonstruksi Aceh." UN Habitat Library, no. 3.

Wahid, Siti Aishah, Sullyfaizura Mohd Rawi, and Norlia Md Desa. 2015. 'Utilization of Plastic Waste in Sand Bricks'. Journal of Basic and Applied Scientific Research 5 (1): 977-82. https://doi.org/10.22214/ijraset.2017.4178.

Wariyatno, Nanang Gunawan, Yanuar Haryanto, and Sumiyanto. 2017. 'Efektivitas Bata Berongga Sebagai Alternatif Material Pengganti Untuk Dinding'. Jurnal Ilmiah Teknik Sipil 21 (2): 136-42.

Watile, R. K., S. K. Deshmukh, and H. C. Muley. 2014. 'Interlocking Brick for Sustainable Housing Development'. International Journal of Science, Spirituality, Business and Technology (IJSSBT) 2 (2): 58-64.

Widyawati, Fauzi, and Tsabit Abdi Haqqi. 2020. 'Pemanfaatan Serat Sisal (Agave Sisalana L.) Dan Limbah Plastik Pet Untuk Pembuatan Bata Ringan CLC (Cellular Lightweight Concrete)'. Jurnal Tambora 4 (1): 21-25.

\section{Author(s) contribution}

Heyder Ahmed contributed to the research concepts preparation, methodologies, investigations, data analysis, visualization, articles drafting and revisions.

Sugini contribute to the research concepts preparation and literature reviews, data analysis, of article drafts preparation and validation. 
ARTEKS : Jurnal Teknik Arsitektur, Volume 6 Issue 3, December 2021

pISSN 2541-0598; eISSN 2541-1217 